\title{
Gender-biased nectar targets different behavioural traits of flower visitors
}

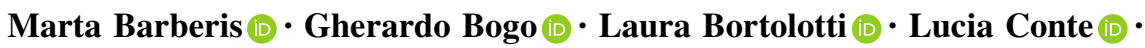 \\ Mattia Alessandrini $\cdot$ Massimo Nepi $[$ - Marta Galloni
}

Received: 8 September 2020/Accepted: 19 November 2020

(C) Springer Nature B.V. 2021

\begin{abstract}
Floral nectar is a chemically complex aqueous solution within which several secondary metabolites have been identified that affect attractiveness for pollinators. Understanding preferences and aversions to nectar quality in flower visitors is crucial since this may influence the patterns of insect floral visitation with consequences on the plant fitness. We hypothesise that nectar chemical variation through different floral sexual phases may affect the number of insect visits that each phase receives. The study was
\end{abstract}

Communicated by Philip Ladd.

Marta Barberis and Gherardo Bogo have contributed equally to this paper.

M. Barberis - L. Conte · M. Alessandrini - M. Galloni Dipartimento di Scienze Biologiche, Geologiche e Ambientali, Università di Bologna, Bologna, Italy

G. Bogo $(\bowtie)$

Grupo de Ecología de la Polinización, INIBIOMA, Universidad Nacional del Comahue-CONICET,

Bariloche, Argentina

e-mail: gherardo1985@hotmail.com

L. Bortolotti

Consiglio per la Ricerca in Agricoltura e l'analisi dell'economia Agraria, Centro di Ricerca Agricoltura e

Ambiente (CREA-AA), Bologna, Italy realized on a population of Echium vulgare L. growing in a natural area close to Bologna. Nectar was collected from functionally male and female flowers to investigate its chemical composition through the HPLC technique. A total of $200 \mathrm{~min}$ of behavioural observations on foraging insects was also carried out. Variation in nectar traits has been detected for the amino acid spectrum. The proportion of protein amino acids appeared to be significantly higher in male-phase flowers. This may explain the significantly higher number of visits on male flowers than expected observed for all bee taxa (except Hoplitis adunca females). Functionally male flowers presented higher concentrations of phenylalanine, whilst proline was

\footnotetext{
M. Alessandrini

Department of Biochemistry of Plant Secondary

Metabolism, University of Hohenheim, Garbenstr. 30, 70599 Stuttgart, Germany

M. Nepi

Dipartimento di Scienze della Vita, Università di Siena, Siena, Italy
} 
highly represented in functionally female flowers. Since a recent study demonstrated that hymenopterans can oxidize proline at a high rate for ATP production, we can hypothesise that the quality of nectar offered by the two sexually distinct floral phases targets different insect behavioural traits and likely ensures an optimal pattern of visit among flower sexes, which are unequally distributed within and among individuals in the population.

Keywords Echium vulgare . Flower visitors · Inbreeding avoidance $\cdot$ Nectar chemistry $\cdot$ Plantpollinator interactions

\section{Introduction}

Floral nectar is a chemically complex aqueous solution in which the main components comprise sugars, followed by amino acids (Nicolson and Thornburg 2007). In recent decades considerable progress has been made in providing evidence that points to the involvement of nectar chemistry in the interactions between plants and a variety of organisms (Nepi 2014; Stevenson et al. 2017). Although there is wide variability in nectar traits (Pacini et al. 2003; Nocentini et al. 2013; Irwin et al. 2014), a general paradigm shared by plants is balancing nectar chemical composition in order to not deter specific pollinators exceeding their tolerance thresholds (Baker and Baker 1975; Adler 2000; Nicolson 2007; Wright et al. 2013; Stevenson et al. 2017). For example, a small increase in nectar sugar concentration can increase its viscosity (Harder 1986; Nicolson and Thornburg 2007), which is strongly related to the energy required by nectar consumers to visit flowers (Corbet 1978; Josens and Farina 2001; Borrell and Krenn 2006; Nepi and Stpiczyńska 2006; Kim et al. 2011).

After sugars the most abundant nectar solutes are the amino acids (Baker and Baker 1982; Nepi et al. 2012; Bogo et al. 2019). A study conducted by Inouye and Waller (1984) showed a general decline in nectar consumption in honeybees as amino acid concentrations increased, despite evidence supporting the preference for amino acid enriched sugar solutions in insects (Alm et al. 1990; Bertazzini et al. 2010; Bogo et al. 2019). Amino acids also contribute to the taste of nectar, stimulating specific insects' labellar chemoreceptors (Gardener and Gillman 2002). Among protein amino acids, Inouye and Waller (1984) found that phenylalanine and leucine were phagostimulant for honeybees at all concentrations tested, even at those that in the case of other amino acids resulted in deterrence. In the same way, a preference in honeybees for proline enriched artificial nectar was reported (Carter et al. 2006; Bertazzini et al. 2010), as well as a strong phagostimulatory activity (Nicolson and Thornburg 2007; Petanidou 2007).

Beside primary metabolites (such as sugars and amino acids) an array of secondary metabolites with different chemical natures have been identified in nectar and all of them positively or negatively affect attractiveness to pollinators, showing effects which depend on metabolite concentration and pollinators' sensitivity (Baker and Baker 1977, 1982; Faegri and van der Pij1 1979; Adler 2000; Stevenson et al. 2017). Among them non-protein amino acids (NPAAs) have been detected in nectar (Nicolson and Thornburg 2007; Petanidou 2007; Nepi et al. 2012). Despite that they can constitute a large portion of the amino acidic content of floral nectar, little is known about their role in determining pollinators' preferences and feeding behaviour. For some of those, such as $\gamma$-aminobutyric acid, a phagostimulant function has been reported in some caterpillars and adult beetles (Mitchell and Harrison 1984; Schoonhoven et al. 2005), whilst Bogo et al. (2019) found that both bumblebees and honeybees showed higher consumption of sucrose solution enriched with B-alanine, but exhibited the effect at different concentrations.

Understanding preferences and aversions to nectar traits is crucial since they likely influence the patterns of floral visitation by nectar consumers and thus the plant inbreeding and outbreeding rate within a population. Minimal inbreeding is predicted when pollinators visit a small fraction of the open flowers on a plant (Iwasa et al. 1995; Ohashi and Yahara 2001): this behaviour may be enhanced by within-plant variation in nectar, as occurs in plants showing gender-biased nectar production (Feinsinger 1978; Pyke 1978; Rathcke 1992). Despite many studies having already addressed the subject of gender-biased nectar composition, most of them investigated the existence of bias in relation to nectar volume or sugar content only (Langenberger and Davis 2002; Canto et al. 2011; Fisogni et al. 2011; Stpiczyńska et al. 2015; Antoń 
et al. 2017; Jacquemart et al. 2019; Konarska and Masierowska 2020) and few reported the observation of insect visit bias (Carlson and Harms 2006 and references therein).

In this study we focused on the many-flowered hermaphrodite species Echium vulgare L., a selfcompatible plant which shows both herkogamy and incomplete protandry, that avoids self-pollination within the same flower, but within which geitonogamy can still occur (Rademaker et al. 1999). Melser et al. (1999) reported evidences of inbreeding depression in $E$. vulgare, finding a significant decline in siring success when selfing occurs. A study on geitonogamy conducted by Rademaker et al. (1999), though, found a consistently lower percentage of selfing rate than expected. Also, they reported that bumblebees visited only a small fraction of the flowers on E. vulgare as a result of the presence of different flower stages simultaneously occurring on a single individual plant.

E. vulgare represents an important food resource for many insect visitors, despite containing toxic pyrrolizidine alkaloids in both nectar and pollen (Lucchetti 2017). The pollen contains high concentrations of pyrrolizidines, whilst more than 500 times lower concentrations are found in nectar (Lucchetti et al. 2016). For this reason, only a few taxa show oligolecty or floral constancy on E. vulgare by actively collecting pollen for larval nourishment (Cane and Sipes 2006; Burger et al. 2010; Filella et al. 2011), even if its flowers are visited by a wide spectrum of insect taxa among which bumblebees have often been reported as main pollinators (Corbet 1978; Klinkhamer and de Jong 1990; Pappers et al. 1999; Rademaker et al. 1999).

Here, we examined if floral visitation pattern may be influenced by variations in the chemical composition of nectar through different floral stages, and thus we investigated (i) whether E. vulgare produces a gender-biased nectar for volume, sugar and amino acid composition and (ii) if flower visitation rates of insects looking for nectar varied among different floral stages.

\section{Material and methods}

Study site

The activity in the field was carried out in June 2018 and took place in the Parco Belpoggio, a public park managed since 2010 by the WWF, in San Lazzaro di Savena (Bologna, Italy). The area is situated close to the protected area Parco dei Gessi Bolognesi e

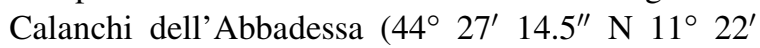
$\left.58.3^{\prime \prime} \mathrm{E}\right)$. The studied population was located on an open prairie along the public pathway.

\section{Study species}

Echium vulgare L. is a perennial hemicryptophyte belonging to the family Boraginaceae. It is distributed in Europe, Asia and North America and it shows a long flowering period, ranging between June and October. Flower anthesis lasts 3-4 days and flowers show an incomplete protandry (Melser et al. 1997): the anthers are often dehiscent already at the bud stage, while the stigma becomes receptive only hours after the flower opening.

In this study we considered three phases of floral development: closed flower (Bud), functionally male (M) and functionally female (F) flowers. The male phase was represented by an open flower presenting pollen with non receptive stigma, whilst the female phase was recognised as soon as the stigma became bifid and receptive.

\section{Plant phenology}

On the first day of the study we counted all plants and inflorescences per plant constituting the population (an area of approximately $600 \mathrm{~m}^{2}$ ) and we observed all open flowers to assess whether the phenomenon of gynodioecy, firstly described in E. vulgare populations by Darwin (1877), occurred in our study population. Each day, prior to visitor observations, on the same patch we recorded the number of flowers per developmental stage. Two fixed patches were alternatively considered: the first one was a single plant carrying 6 inflorescences while the second one was made up of 6 plants carrying one or two inflorescences each.

Nectar quality

\section{Sampling}

We collected nectar samples by means of Drummond Microcaps (3-5 $\mu \mathrm{L}$; Drummond Scientific Co., Broomall, PA), we transferred samples to Eppendorf tubes filled with $100 \mu \mathrm{L}$ of pure ethanol, and then we 
took them to the laboratory in thermal bags where they were kept at $5{ }^{\circ} \mathrm{C}$ until analyses. We collected each sample from multiple flowers at the same floral stage in order to reach a minimum volume of $2 \mu \mathrm{L}$ needed for the sugar and amino acid analyses. In order to let the nectar accumulate, flowers were bagged in the morning for $2 \mathrm{~h}$ prior to sampling; all nectar present in the selected flowers was collected.

We collected a total of 8 nectar samples, each one from 3 to 13 male flowers belonging to 1-7 plants, and a total of 8 samples from 2 to 9 female flowers belonging to 1-3 plants. Both sugar and amino acid compositions were investigated on these samples. We then collected 14 additional samples from 1 to 22 buds belonging to 1-10 plants. Since the amount of nectar presents in the buds was very low, the minimum volume of $2 \mu \mathrm{L}$ needed for amino acid analysis could not be reached and thus these samples were tested for sugar composition only.

\section{Sugar analysis}

Sugar content was analysed by HPLC technique through a Waters LC1 with refractive index detector (Waters 2410) connected to the output of a REZEX RCM Monosaccharide column (Phenomenex, $300 \mathrm{~mm} \times 7.8 \mathrm{~mm}$, grain $8 \mu \mathrm{m})$ maintained at $85^{\circ} \mathrm{C}$. Water (MilliQ, pH 7) was used as mobile phase at a flow rate of $0.6 \mathrm{~mL} \mathrm{~min}^{-1} ; 20 \mu \mathrm{L}$ of sample and standard solutions of sucrose, glucose and fructose were also injected (Nocentini et al. 2012).

\section{Amino acids analysis}

Amino acid analysis was performed by gradient HPLC with an ion exchange Novapack C18 $(15 \mathrm{~mm} \times 4.6$ $\mathrm{mm}$ ) cartridge with guard column maintained at $37{ }^{\circ} \mathrm{C}$ and a Waters 470 scanning fluorescence detector (excitation at $295 \mathrm{~nm}$, detection at $350 \mathrm{~nm}$ ). A solvent composed of TEA-phosphate buffer ( $\mathrm{pH}$ 5.0) mixed with a 6:4 acetonitrile-water solution was used as mobile phase at a flow rate of $1.0 \mathrm{~mL} \mathrm{~min}^{-1}$. According to AccQtag protocol (Waters Corp.), the selected volume of each reconstituted sample was amino acid derivatized (Cohen and Micheaud 1993) with AQC fluorescent reagent and $0.02 \mathrm{M}$ borate buffer ( $\mathrm{pH}$ 8.6). In addition to all the protein amino acids, standard solutions of $\beta$-alanine, citrulline, $\mathrm{L}^{-}$ homoserine, $\alpha$-aminobutyric acid (AABA), $\gamma$ - aminobutyric acid (GABA), hydroxyproline, ornithine and taurine were also used (Nocentini et al. 2012).

\section{Flower visitors' observations}

We carried out observations on flower visitors on the two fixed patches described previously, on 7 nonsequential days. Every survey consisted of two 15-min periods separated by $10 \mathrm{~min}$ of rest, adapting the protocol of Fisogni et al. (2016). Every day we performed 1 to 3 surveys, between 10:30 am and 3:00 pm and under favourable weather conditions, for a total of $200 \mathrm{~min}$ of observation. Once a visitor left the patch, we counted the following approaching insect belonging to the same taxon as a different individual. Recorded data concerned the food resource collected (nectar or pollen, observing if the insect inserted its mouth-parts deeply inside the corolla or if it manipulated the anthers) and the number of male and female flowers approached per visit. We also recorded the visitor's taxon, indicating the taxonomic level in as much detailed as possible, and its sex.

After each observation period, we performed a 15-min period of net sampling throughout the area, collecting insects that alighted on flowers of $E$. vulgare. Captured individuals were put in separate vials with ethyl acetate and brought to the laboratory where they were pinned in entomological boxes and inspected under a dissecting microscope for taxonomic identification.

Data analysis

Sugar and amino acid quantities and the mean nectar volume were calculated per single flower. Total sugar concentration was calculated as the sum of sucrose, fructose and glucose concentrations.

Data on nectar composition were grouped by floral stage and tested to assess homogeneity of variances and normality of distribution (Bartlett test and Shapiro Wilk test).

Data on sugars per flower, total sugar concentration and sucrose per flower were square root transformed to achieve normality. When the transformed data failed to match normality, we applied the corresponding nonparametric analyses.

To investigate whether the floral stage affected sugar content and volume a one-way ANOVA followed by Tukey's HSD post hoc test with 
Benjamini-Hochberg correction for 'false discovery rate' (Verhoeven et al. 2005) were performed. When distribution was not normal a Kruskal Wallis H-test followed by a Mann Whitney pairwise comparison with Benjamini-Hochberg correction were carried out instead.

Data on single amino acid concentrations were $\ln$ transformed to achieve normality when needed and a Student $t$-test was applied in all analyses.

For both phenological stages (functionally male and functionally female flowers), three diversity indices were calculated on the nectar amino acid composition. The first index was the reciprocal Simpson's diversity index $1-D$ of the nectar amino acidic spectrum. $D$ was calculated as $D=\sum_{i=1}^{n}\left(\frac{n i}{n}\right)^{2}$, where $n \mathrm{i}$ is the abundance of the $i$ th amino acid and $n$ is the total mean concentration (Ranjbar et al. 2017). This index ranges from 0 (one amino acid dominates the spectrum) to 1 (all amino acids equally represented) (Harper 1999).

The second was the Shannon's $H$ - index, by taking into account mean amino acid concentrations as well as the total mean concentration of amino acids. The index is calculated as $H=-\sum_{i} \frac{n i}{N} \ln \frac{n i}{N}$, where $n i$ is the mean concentration for the $i$ th amino acid and $N$ is the total number of amino acids (Magurran 2004). This index varies from 0 for a spectrum with only a single amino acid to high values for a spectrum with many amino acids, each represented by relatively low concentrations (Harper 1999; Hubálek 2000; Fattorini et al. 2016).

The third one was the Buzas and Gibson's evenness index, a measure of the relative abundance of the different amino acids within the floral stage. The index is calculated as the proportion of equally dominant amino acid in the phenological stage $E=e^{H} / S$, where $H$ is Shannon's $H$ index and $S$ is the number of amino acids within the floral stage. This index ranges from 0 (highest dominance by a single amino acidic species) to 1 (all amino acids have the same abundance) (Buzas and Hayek 2010; Fattorini et al. 2016).

Insect visit data were first analysed by comparing the observed number of male and female flowers visited to the expected ones by $\chi^{2}$ test. The expected number of visits was calculated on the basis of the ratio between the functionally male and the functionally female flowers occurring in the population.
Frequencies of male flowers visited by each taxon were compared by a Kruskal Wallis H-test followed by a Mann-Whitney pairwise comparison with Benjamini-Hochberg correction.

All data are presented as mean $\pm \mathrm{SE}$ and all statistics were performed using $\mathrm{R}$ software (version 3.6.1) with the significance level set at 0.05 .

\section{Results}

Plant phenology

In June 2018, the studied population contained 47 flowering individuals, all hermaphrodites. The mean number of inflorescences per plant was $3.17 \pm 0.44$, while the mean number of cymes per inflorescence was $14.30 \pm 0.81$. Moreover, the mean number of male flowers per inflorescence was $2.69 \pm 0.171$, while the mean number of female flowers per inflorescence was $21.07 \pm 0.858$. On the basis of the data collected on the population structure the ratio of male and female floral stages in the observation patches was determined at 1:9.

Nectar analyses

\section{Sugars and volume}

Mean nectar volume per flower showed a clear trend of increasing in relation to floral age, with volume in buds statistically lower than in both male- and femalephase flowers $(U=15, p=0.009$ and $U=2$, $p=0.001$, respectively). A significant difference for mean sugar quantity per flower was also reported between buds and female-phase flowers (Tukey's HDS: $p=0.028$ ), whilst sugar concentration did not differ significantly among floral stages (Table 1).

A more in depth analysis on sugars reported that hexose sugar quantity per flower in the bud stage differed significantly from both male- and femalephase flowers $(U=12, p=0.008$ and $U=19$, $p=0.018$, respectively), whilst sucrose quantity per flower found in bud differed statistically only from the average amount found in the female stage (Tukey's HDS: $p=0.021$; Table 1). Mean percentage of sucrose per flower did not appear to be significantly different among floral stages (Table 1). 
Table 1 Comparison of nectar volume, sugar and amino acid ( $A A$ amino acids, $P A A$ protein amino acids, NPAA non-protein amino acids) compositions among the three phenological stages (bud, male and female flowers)

\begin{tabular}{|c|c|c|c|c|c|}
\hline Nectar parameters & Bud & Male flower & Female flower & Test value & $p$-value \\
\hline Volume $\left(\mu \mathrm{L}_{\text {flower }}{ }^{-1}\right)$ & $0.159 \pm 0.019 \mathrm{a}$ & $0.427 \pm 0.080 \mathrm{~b}$ & $0.669 \pm 0.135 \mathrm{~b}$ & $\mathrm{H}_{2}=16.83$ & $<0.001$ \\
\hline Total sugar $\left(\mu\right.$ f flower $\left.^{-1}\right)$ & $0.013 \pm 0.006 \mathrm{a}$ & $0.040 \pm 0.013 \mathrm{ab}$ & $0.070 \pm 0.026 \mathrm{~b}$ & $\mathrm{~F}_{2,27}=5.78$ & $<0.001$ \\
\hline Total sugar concentration $\left(\mu \mathrm{g} \mu \mathrm{L}^{-1}\right)$ & $0.089 \pm 0.033$ & $0.094 \pm 0.022$ & $0.090 \pm 0.020$ & $\mathrm{~F}_{2,27}=0.45$ & 0.642 \\
\hline Hexose sugars $\left(\mu\right.$ flower $\left.^{-1}\right)$ & $0.005 \pm 0.004 \mathrm{a}$ & $0.007 \pm 0.001 \mathrm{~b}$ & $0.008 \pm 0.002 \mathrm{~b}$ & $\mathrm{H}_{2}=11.43$ & 0.003 \\
\hline Sucrose $\left(\mu\right.$ fllower $\left.^{-1}\right)$ & $0.009 \pm 0.003 \mathrm{a}$ & $0.033 \pm 0.012 \mathrm{ab}$ & $0.061 \pm 0.024 \mathrm{~b}$ & $\mathrm{~F}_{2,27}=5.63$ & 0.007 \\
\hline Sucrose (\% per flower) & $82.278 \pm 7.824$ & $72.896 \pm 5.776$ & $81.900 \pm 3.817$ & $\mathrm{H}_{2}=4.10$ & 0.129 \\
\hline Total AA (nmol flower ${ }^{-1}$ ) & - & $0.367 \pm 0.061$ & $1.349 \pm 0.611$ & $U=21$ & 0.270 \\
\hline PAA (nmol flower ${ }^{-1}$ ) & - & $0.321 \pm 0.054$ & $1.058 \pm 0.467$ & $U=23$ & 0.372 \\
\hline NPAA (nmol flower ${ }^{-1}$ ) & - & $0.045 \pm 0.007$ & $0.290 \pm 0.145$ & $U=15$ & 0.083 \\
\hline PAA:NPAA ratio & - & $7.31 \pm 0.670$ & $4.65 \pm 0.437$ & $\mathrm{t}_{14}=-3.34$ & 0.005 \\
\hline
\end{tabular}

Values (expressed by mean $\pm \mathrm{SE}$ ) marked with different letters were significantly different according to one-way ANOVA or Kruskal-Wallis test followed by the respective post hoc test with Benjamini-Hochberg correction

\section{Amino acids}

There was no significant difference for total, protein, and non-protein amino acid quantity per flower between male and female flowers, while the ratio between protein and non protein amino acid concentrations was significantly higher for male-phase flowers (Table 1).

The only amino acid with a statistically significant difference was phenylalanine $\left(\mathrm{t}_{15}=2.94, p=0.011\right)$, showing a higher concentration in male floral phase $\left(M=352.7 \pm 63.2 \mathrm{nmol} \mathrm{mL}^{-1}\right.$ and $F=143.6 \pm 32.6 \mathrm{nmol} \mathrm{mL}^{-1}$; Fig. 1).

Among all protein amino acids, proline and phenylalanine showed the highest concentrations: the former appeared to reach higher concentrations in the functionally female stage $\left(674.8 \pm 243.5 \mathrm{nmol} \mathrm{mL}{ }^{-1}\right)$, whilst the latter in the functionally male stage $\left(352.7 \pm 63.2 \mathrm{nmol} \mathrm{mL}{ }^{-1}\right)$. Among non protein amino acids, in both male and female stages GABA showed the highest concentration $\quad\left(51.4 \pm 12.2 \mathrm{nmol} \mathrm{mL}^{-1} \quad\right.$ and $202.0 \pm 73.4 \mathrm{nmol} \mathrm{mL} \mathrm{m}^{-1}$, respectively).

The number of different amino acids (richness) detectable in the male stage was significantly lower than number of amino acids in the female stage $\left(\mathrm{t}_{15}=3.54, p=0.003 ; 16.5 \pm 0.6\right.$ and $19.0 \pm 0.3$, respectively), while no differences were found in Simpson, Shannon and Evenness indices between male and female stages (Table 2).
Insect visit analyses

\section{Flower visitors' abundance}

A total of 215 insect visits were recorded on Echium vulgare during $200 \mathrm{~min}$ of field surveys (Table 3).

Visitors belonged to three orders: Hymenoptera (87.4\%), Lepidoptera (9.8\%) and Diptera (2.8\%). The order Hymenoptera was mainly represented by individuals belonging to the family Megachilidae (59\%), followed by the family Halictidae (26.5\%) and Apidae (14\%). The order Lepidoptera was represented mainly by individuals belonging to the species Macroglossum stellatarum (43\%) and the family Pieridae (43\%). The order Diptera was represented only by 6 individuals belonging to the families Bombyliidae and Syrphidae. The most frequent visitors were solitary bees of the species Hoplitis adunca (42\%).

\section{Flower visitor observations}

Among the 215 insects visiting the plant, we fully recorded data for 189 individuals. Statistical analyses were carried out only on the 112 individuals which were looking for nectar and for which the number of total visits exceeded 5 (Macroglossum stellatarum, Pieridae, Anthidium florentinum, Apis mellifera and Hoplitis adunca). The family Pieridae was analysed as a single taxon in order to reach a total number of visits above 5. Since Hoplitis adunca was the most abundant 


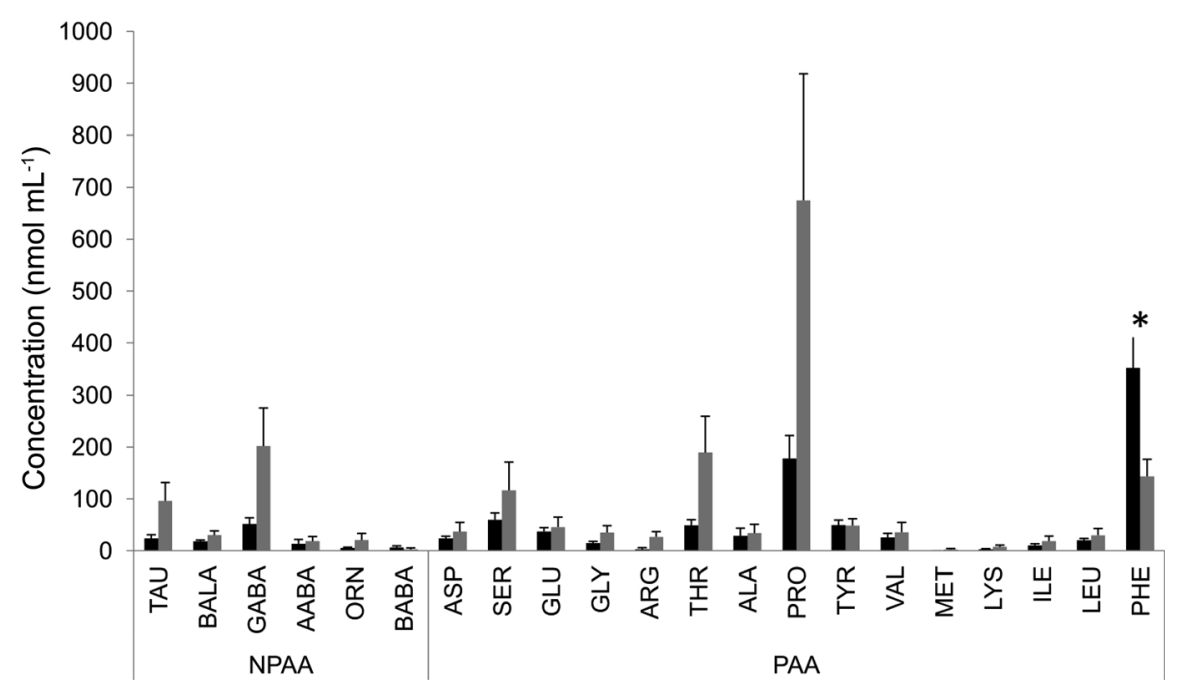

Fig. 1 Amino acid concentrations $\left(\mathrm{nmol} \mathrm{mL} \mathrm{m}^{-1}\right)$ detected in functionally male (dark bars) and in functionally female (light bars) flowers (mean $\pm \mathrm{SE}$ ). Amino acids hydroxyproline, homoserine, citrulline, cysteine, histidine, glutamine, asparagine and L-thyronine were not detected in either floral stages and thus not shown in the graph. The asterisk denotes a statistically significant difference according to Student $t$-test. $N P A A$ non-protein amino acids, $P A A$ protein amino acids

Table 2 Comparison of diversity indices calculated on nectar amino acid concentration between male and female phases (8 samples for both floral phases)

\begin{tabular}{lllrl}
\hline Diversity indices & Male flower & Female flower & $t$ & $p$-value \\
\hline Amino acids richness & $16.50 \pm 0.627$ & $19.00 \pm 0.327$ & 3.54 & 0.003 \\
Simpson & $0.793 \pm 0.035$ & $0.822 \pm 0.024$ & 0.68 & 0.506 \\
Shannon $H$ & $2.109 \pm 0.103$ & $2.233 \pm 0.111$ & 0.82 & 0.428 \\
Evenness & $0.527 \pm 0.059$ & $0.511 \pm 0.050$ & -0.20 & 0.842 \\
\hline
\end{tabular}

taxon and the only species strongly oligolectic on Echium, we therefore decided to analyse the sexes separately.

Although nectar is produced before flower opening and insects can force the bud searching for nectar (personal observation), this event occurred very rarely. Consequently, we did not consider the phenological stage bud in these analyses.

For each insect taxon, we compared the number of visits to male and female flowers with the expected ones, calculated according to the ratio 1:9 between male and female flowers registered in the studied population.

Regarding the number of male flowers visited, no significant difference was reported for lepidopterans (Pieridae spp., Macroglossum stellatarum) and for females Hoplitis adunca, while Anthidium florentinum, Apis mellifera and Hoplitis adunca males visited more male flowers than expected (Table 4). The number of female flowers visited was never statistically different from that expected.

The frequency of male flowers visited in relation to the total number of flowers visited among taxa was statistically different $\left(\mathrm{H}_{4}=14.01, p=0.016\right)$. Statistical analyses confirmed that the female Hoplitis adunca visited fewer male flowers than did Anthidium florentinum $(U=65, p=0.002)$, Apis mellifera ( $U=48, p=0.002)$ and Macroglossum stellatarum $(U=28.5, p=0.043$; Fig. 2).

\section{Discussion}

Our studied population did not show the phenomenon of gynodioecism, as all flowers were hermaphrodite, and our data confirmed the ratio of 1:9 found by 
Table 3 Echium vulgare visitors recorded in June 2018 (215 visits in total), their abundance and the percentage of them looking for nectar as reward

\begin{tabular}{|c|c|c|c|c|}
\hline Order & Family & Species & Relative frequency & Looking for nectar $(\%)$ \\
\hline Hymenoptera & Apidae & Apis mellifera Linnaeus 1758 & 0.079 & 100 \\
\hline Hymenoptera & Apidae & Bombus pascuorum (Scopoli 1763) & 0.005 & 100 \\
\hline Hymenoptera & Apidae & Ceratina (Latreille 1802) sp. & 0.023 & 100 \\
\hline Hymenoptera & Apidae & Eucera (Scopoli 1770) sp. & 0.018 & 100 \\
\hline Hymenoptera & Halictidae & $\begin{array}{l}\text { Lasioglossum interruptum (Panzer 1798) } \\
\text { Lasioglossum laticeps (Schenck 1869) } \\
\text { Lasioglossum corvinum (Morawitz 1878) }\end{array}$ & 0.233 & 0 \\
\hline Hymenoptera & Halictidae & Halictus subauratus (Rossi 1792) & 0.005 & 100 \\
\hline Hymenoptera & Colletidae & Hylaeus cfr. angustatus (Schenck 1859) & 0.005 & 100 \\
\hline Hymenoptera & Megachilidae & Anthidium florentinum (Fabricius 1775) & 0.102 & 100 \\
\hline Hymenoptera & Megachilidae & Hoplitis adunca (Panzer 1798) & $\begin{array}{l}\text { Male: } 0.191 \\
\text { Female: } 0.219\end{array}$ & $\begin{array}{l}\text { Male: } 100 \\
\text { Female: } 66.6^{\mathrm{a}}\end{array}$ \\
\hline Diptera & Bombyliidae & Bombylius (Linnaeus 1758) sp. & 0.009 & 100 \\
\hline Diptera & Syrphidae & Syrphidae (Latreille 1802) sp. & 0.019 & 0 \\
\hline Lepidoptera & Hesperiidae & $\begin{array}{l}\text { Hesperia comma (Linnaeus 1758) } \\
\text { Thymelicus acteon (Rottemburg 1775) }\end{array}$ & 0.019 & 100 \\
\hline Lepidoptera & Papilionidae & Iphiclides podalirius (Linnaeus 1758) & 0.005 & 100 \\
\hline Lepidoptera & Pieridae & $\begin{array}{l}\text { Pieris brassicae (Linnaeus 1758) } \\
\text { Pieris mannii (Mayer 1851) } \\
\text { Colias croceus (Fourcroy 1785) } \\
\text { Pontia edusa (Fabricius 1777) }\end{array}$ & 0.042 & 100 \\
\hline Lepidoptera & Sphingidae & Macroglossum stellatarum (Linnaeus 1758) & 0.042 & 100 \\
\hline
\end{tabular}

avalue calculated only on individuals with fully recorded data $(\mathrm{n}=21)$

Rademaker et al. (1999) between functionally male and functionally female flowers.

Our analyses confirmed that nectar is secreted in the bud, as reported by Chwil and Weryszko-Chmielewska (2011). Contrary to Klinkhamer and de Jong (1990), we found that nectar volume, as well as sugar quantity per flower, increased with the age of the flower (from bud to female phase), although the positive trend between male and female phases was not statistically significant. Both quantity of hexose sugars and sucrose per flower increased with the age of the flower, the latter reaching a mean almost sevenfold higher in functionally female flowers than the mean amount found in the bud stage and almost twice the amount found in functionally male flowers. At the same time, the mean percentage of sucrose per flower appeared to be lower in male-phase flowers, even though not significantly, meaning that the total sugar increase in relation to floral age is due to the rise of nectar volume, since total sugar concentration and composition remained constant during the entire flower phenology. The existence of nectar homeostasis mechanisms which actively maintain a constant nectar sugar concentration to ensure pollinator visits has been previously reported in other species (Nepi and Stpiczyńska 2008; Nepi et al. 2011).

When we compared the number of insect visits on male and female flowers observed to the expected ones, all bee taxa except female Hoplitis adunca showed a higher number of visits to male flowers than expected. This result could be explained by the higher proportion of protein amino acids found in the male stage: preferences have often been reported in bees for protein amino acid enriched solutions (Inouye and Waller 1984; Bertazzini et al. 2010; Hendriksma et al. 2014), suggesting that flower visitors may actively choose to visit functionally male flowers. Comparable results have been reported by Klinkhamer and de Jong 
Table 4 Male (a) and female (b) flowers visited by each taxon (mean \pm SE)
Chi-square test is calculated on the basis of the ratio 1:9 between male and female flowers occurred in the studied population

\begin{tabular}{llccr}
\hline Taxon & Male flowers visited & $\chi^{2}$ & d.f & $p$-value \\
\hline (a) & & & & \\
Anthidium florentinum & $0.96 \pm 0.192$ & 37.80 & 21 & 0.014 \\
Apis mellifera & $1.59 \pm 0.384$ & 39.39 & 16 & $<0.001$ \\
Hoplitis adunca male & $0.51 \pm 0.100$ & 70.51 & 40 & 0.002 \\
Hoplitis adunca female & $0.14 \pm 0.143$ & 8.50 & 13 & 0.810 \\
Macroglossum stellatarum & $2.33 \pm 0.799$ & 4.54 & 8 & 0.806 \\
Pieridae & $0.33 \pm 0.236$ & 5.21 & 8 & 0.735 \\
\hline Taxon & Female flowers visited & $\chi^{2}$ & d.f & $p$-value \\
\hline (b) & & & & \\
Anthidium florentinum & $3.95 \pm 0.826$ & 4.20 & 21 & 1.000 \\
Apis mellifera & $7.47 \pm 1.652$ & 4.38 & 16 & 0.998 \\
Hoplitis adunca male & $2.37 \pm 0.312$ & 7.84 & 40 & 1.000 \\
Hoplitis adunca female & $1.64 \pm 0.199$ & 0.94 & 13 & 1.000 \\
Macroglossum stellatarum & $15.67 \pm 14.696$ & 0.50 & 8 & 1.000 \\
Pieridae & $4.22 \pm 1.656$ & 0.58 & 8 & 1.000 \\
\hline
\end{tabular}

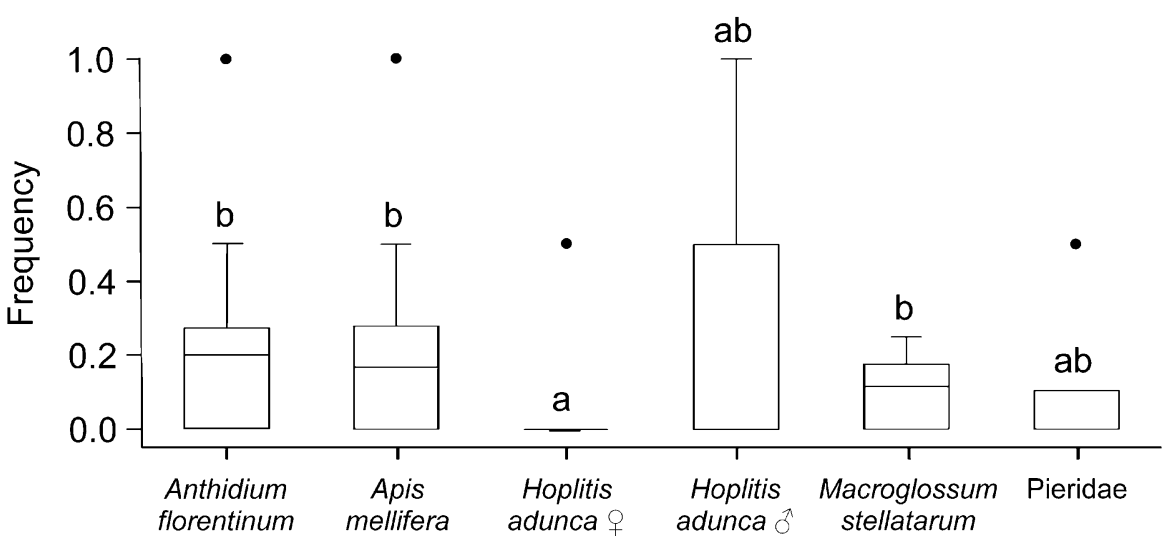

Fig. 2 Frequency of male flowers visited by each taxon. Different letters denote statistical differences according to Kruskal Wallis H-test followed by MannWithney pairwise comparison with Benjamini-Hochberg correction $(p<0.05)$ may simply collect the resource at different time of the day.

Despite Lepidoptera having been reported to prefer nectar rich in PAAs (Baker and Baker 1986; Erhardt and Rusterholz 1998), our study reports that Pieridae butterflies visited as many male flowers as expected, indicating that these insects did not actively look for functionally male flowers (containing a higher proportion of protein amino acids). A study conducted by Alm et al. (1990) showed that male individuals of the species Pieris rapae do not discriminate between artificial nectars containing sugar only or sugar solution enriched with protein amino acids, and Romeis and Wackers (2000) reported that feeding 
and source-selection in Pieris brassicae is elicited by sucrose more than protein amino acids. We report a similar result for the species Macroglossum stellatarum, but to date no study has been done in order to assess amino acid preferences in the species and whether taste receptors on the proboscis can sense their presence in nectar remains unsubstantiated (Stöckl and Kelber 2019).

Nectar of male-phase flowers in E. vulgare presented, among all the amino acids, the highest concentration of phenylalanine, representing an average of $35 \%$ of total amino acid content. Phenylalanine is an essential protein amino acid (de Groot 1953) and several studies proved that it exerts a phagostimulatory effect on several insects, especially on honey bees, and it is strongly correlated with pollinator preferences (Inouye and Waller 1984; Hendriksma et al. 2014; Tiedge and Lohaus 2017; Seo et al. 2019). Consequently, this could explain the higher frequency of visit on male flowers than expected. A correlation between phenylalanine concentration and nectar feeding by Megachilids, that were the more numerous pollinators in our study, was demonstrated in a phriganic community, a plant association typical of the East Mediterranean (Petanidou et al. 2006).

Proline, instead, represented the most concentrated amino acid in functionally female flowers, and the second in the early-stage functionally male flowers (representing more than $30 \%$ and almost $20 \%$ of the total amino acid content, respectively). This nonessential amino acid, commonly found in nectar (Nicolson and Thornburg 2007), can stimulate the insect salt cell increasing intensity of feeding behaviour (Hansen et al. 1998; Wacht et al. 2000). Proline also represents an energy substrate to fuel the earliest or most expensive stages of insect flight (Micheu et al. 2000; Gade and Auerswald 2002), resulting in shortterm bursts of energy production (Teulier et al. 2016).

Finally, in both male- and female-phase flower nectar GABA showed the highest concentration among the non-protein amino acids representing more than $5 \%$ and $9 \%$ of total amino acid content, respectively. Recent studies indicated that GABA could affect both insects' physiology and behaviour, feeding rate and flight muscles performances (Shelp et al. 2017; Felicioli et al. 2018; Bogo et al. 2019). Besides GABA, or possibly the combination of GABA and $\mathrm{NaCl}$, can constitute an important nectar phagostimulant and its presence correlates with visits by an array of pollinators such as long tongued bees, ex-anthophorid and andrenid bees, as well as anthomyiid and syrphid flies (Petanidou 2007 and reference therein).

The spectrum of visitors recorded through our observations confirm that reported by previous studies stating that flowers of E. vulgare are visited by hummingbird hawkmoths (Aguado Martìn et al. 2017), bees, bee flies (Proctor et al. 1996) and syrphids (Willmer and Finlayson 2014). Also, even though the species has often been reported as mainly pollinated by bumblebees (Corbet 1978; Klinkhamer and de Jong 1990; Pappers et al. 1999; Rademaker et al. 1999), we observed only one individual of Bombus pascuorum visiting the flowers. Pollinators of wide spread plant species can vary in relation to their geographical distribution (Armbruster 1985; Thompson 2006; Pérez-Barrales et al. 2007) and, moreover, as reported by Lázaro et al. (2010), the plant and pollinators assemblages of an entire community may also influence the composition of visitors of a particular species by determining, for instance, the strength of competition or the intensity of attraction to that species rather than another. Thus, the scarcity of bumblebees observed on Echium vulgare in 2018 may either depend on several factors and/or reflect a temporal fluctuation in the species composition of the pollinator community, as previously reported by many studies (Cane et al. 2005; Petanidou et al. 2008; Dupont et al. 2009).

\section{Conclusions}

The inbreeding avoidance hypothesis states that some mechanisms develop within a species in order to prevent breeding among related individuals and its damaging effects on fitness (Darwin 1876, 1877; Charlesworth and Charlesworth 1987). In dichogamous species, gender-biased nectar often occurs (Carlson and Harms 2006; Stpiczyńska et al. 2015; Konarska and Masierowska 2020), and this, according to the mentioned above hypothesis, may contribute to decrease geitonogamous selfing through its effects on a pollinator's behaviour (Carlson and Harms 2006). Our results suggest that the quality of nectar offered by the two sexually distinct floral phases may target different insect needs, thus affecting simultaneously different behavioural traits and ensuring an optimal 
pattern of visit among functionally different floral stages, unequally present in the population throughout the anthesic period. The more nutritional nectar found in the less frequent sexual phase occurring in the population (male flowers) may enhance movements among plants by encouraging "better-resource hunt", whilst the flight efforts accomplished for doing so may be sustained by a rapidly oxidable fuel such proline offered in female-phase flowers. In the light of this hypothesis, it appears clear that gender-biased nectar studies in dichogamous, many-flowered species should be undertaken in relation to the occurrence of floral sexual phases in the population (when a bias in the frequency of sex occurrence exists).

Despite no study yet providing strong scientific evidence that gender-biased nectar in fact reduces inbreeding (Carlson and Harms 2006), it is reasonable to assume that by offering variable quality nectar through sexually different floral phases the plant may produce a mosaic of food targeting different pollinator behavioural traits aiming to promote cross-pollination.

Acknowledgements Thanks to Simone Flaminio for help with the insect identification, to Chiara Stanzani, Alessandria Tria and Alessandra Alma for help with the field work, and to Emanuele Giordano and Massimo Guarnieri for help with HPLC analyses.

Author contributions MB and GB share the first authorship. MG, MN, LC and LB conceived and designed the experiments. GB, MA and MG performed the experiments. HPLC analyses were executed by MN. MB and GB analysed data and wrote the paper. All authors read, provided editorial advice and approved the final manuscript.

Data availability Data available from the Zenodo Digital Repository: https://doi.org/10.5281/zenodo.4271937.

\section{Compliance with ethical standards}

Conflict of interest The authors declare that they have no conflict of interest.

\section{References}

Adler LS (2000) The ecological significance of toxic nectar. Oikos 91:409-420. https://doi.org/10.1034/j.1600-0706. 2000.910301.x

Aguado Martìn LO, Fereres Castiel A, Viñuela Sandoval E (2017) Guía de campo de los polinizadores de España, 2nd edn. Ediciones Paraninfo S.A., Madrid

Alm J, Ohnmeiss TE, Lanza J, Vriesenga L (1990) Preference of cabbage white butterflies and honeybees for nectar that contains amino acids. Oecologia 84:53-57. https://doi.org/ 10.1007/BF00665594

Antón S, Denisow B, Komoń-Janczara E, Targoński Z (2017) Nectary and gender-biased nectar production in dichogamous Chamaenerion angustifolium (L.) Scop. Plant Species Biol 32:380-391. https://doi.org/10.1111/1442-1984. 12169

Armbruster WS (1985) Patterns of character divergence and the evolution of reproductive ecotypes of Dalechampia scadens (Euphorbiaceae). Evolution 39:733-752. https://doi. org/10.1111/j.1558-5646.1985.tb00416.x

Baker HG, Baker I (1975) The study of nectar-constitution and pollinator plant coevolution. In: Gilbert LE, Raven PH (eds) Coevolution of plants and animals. University of Texas Press, Austin, pp 100-140

Baker HG, Baker I (1977) Intraspecific constancy of floral nectar amino acid complements. Bot Gaz 138:183-191. https://doi.org/10.1086/336914

Baker HG, Baker I (1982) Chemical constituents of nectar in relation to pollination mechanisms and phylogeny. In: Nitecki MH (ed) Biochemical aspects of evolutionary biology. Univeristy of Chicago Press, Chicago, pp 131-171

Baker HG, Baker I (1986) The occurrence and significance of amino acids in floral nectars. Plant Syst Evol 151:175-186

Bertazzini M, Medrzycki P, Bortolotti L, Maistrello L, Forlani G (2010) Amino acid content and nectar choice by forager honeybees (Apis mellifera L.). Amino Acids 39:315-318. https://doi.org/10.1007/s00726-010-0474-x

Bogo G, Bortolotti L, Sagona S, Felicioli A, Galloni M, Barberis M, Nepi M (2019) Effects of non protein amino acids in nectar on bee survival and behaviour. J Chem Ecol 45:278-285. https://doi.org/10.1007/s10886-018-01044-2

Borrell BJ, Krenn HW (2006) Nectar feeding in long-proboscid insects. In: Herrel A, Speck T, Rowe N (eds) Ecology and biomechanics: a mechanical approach to the ecology of animals and plants. CRC Press, Boca Raton, pp 185-211

Burger H, Ayasse M, Häberlein SS, Dötterl S (2010) Echium and Pontechium specific floral cues for host-plant recognition by the oligolectic bee Hoplitis adunca. S Afr J Bot 76:788-795. https://doi.org/10.1016/j.sajb.2010.08.003

Buzas MA, Hayek LAC (2010) Surveying natural populations. Quantitative tools for assessing biodiversity, 2nd edn. Columbia University Press, New York

Cane JH, Sipes S (2006) Floral specialization by bees: analytical methodologies and a revised lexicon for oligolecty. In: Waser N, Ollerton J (eds) Plant-Pollinator Interactions: from specialization to generalization. University of Chicago Press, Chicago, pp 99-122

Cane JH, Minckley R, Kervin L, Roulston T (2005) Temporally persistent patterns of incidence and abundance in a pollinator guild at annual and decadal scales: the bees of Larrea tridentata. Biol J Linn Soc 85:319-329. https://doi.org/10. 1111/j.1095-8312.2005.00502.x

Canto A, Herrera CM, Garcìa IM, Pérez R, Vaz M (2011) Intraplant variation in nectar traits in Helleborus foetidus (Ranunculaceae) as related to floral phase, environmental conditions and pollinator exposure. Flora 206:668-675. https://doi.org/10.1016/j.flora.2011.02.003

Carlson J, Harms KE (2006) The evolution of gender-biased nectar production in hermaphrodite plants. Bot Rev 
72:179-205. 8101(2006)72[179:TEOGNP]2.0.CO;2

Carter C, Sharoni S, Yehonatan L, Palmer RG, Thornburg R (2006) A novel role for proline in plant floral nectars. Sci Nat 93:72-79. https://doi.org/10.1007/s00114-005-0062-1

Charlesworth D, Charlesworth B (1987) Inbreeding depression and its evolutionary consequences. Annu Rev Ecol Syst 18:237-268. https://doi.org/10.1146/annurev.es.18. 110187.001321

Chwil M, Weryszko-Chmielewska E (2011) Nectar production and pollen yield of Echium vulgare L. in the climatic conditions of Lublin. Acta Sci Pol Hortorum Cultus 10:187-196

Cohen SA, Micheaud DP (1993) Synthesis of a fluorescent derivatizing reagent, 6-aminoquinolyl-N-hydroxysuccinimidyl carbamate, and its application for the analysis of hydrolysate amino acids via High Performance Liquid Chromatography. Anal Biochem 211:279-287. https://doi. org/10.1006/abio.1993.1270

Corbet SA (1978) Bee visits and the nectar of Echium vulgare L. and Sinapis alba L. Ecol Entomol 3:25-37. https://doi.org/ 10.1111/j.1365-2311.1978.tb00900.x

Darwin CR (1876) The effects of cross and self fertilization in the vegetable kingdom. Murray, London

Darwin CR (1877) The different forms of flowers on plants of the same species. Murray, London

De Groot AP (1953) Protein and amino acid requirements of the honeybee (Apis mellifera L.). Physiol Comp Oecol 3:1-83. https://doi.org/10.1371/journal.pone.0034137

Dupont YL, Padrón B, Olesen JM, Petanidou T (2009) Spatiotemporal variation in the structure of pollination networks. Oikos 118:1261-1269. https://doi.org/10.1111/j.16000706.2009.17594.x

Erhardt A, Rusterholz HP (1998) Do peacock butterflies (Inachis io L.) detect and prefer amino acids and other nitrogenous compounds? Oecologia 117:536-542. https:// doi.org/10.1007/s004420050690

Faegri K, van der Pijl L (1979) The principles of pollination ecology, 3rd edn. Pergamon Press, Oxford. https://doi.org/ 10.1016/C2009-0-00736-3

Fattorini S, Rigal F, Cardoso P, Borges PAV (2016) Using species abundance distribution models and diversity indices for biogeographical analyses. Acta Oecol 70:21-28. https://doi.org/10.1016/j.actao.2015.11.003

Feinsinger P (1978) Ecological interactions between plants and hummingbirds in a successional tropical community. Ecol Monogr 48:269-287. https://doi.org/10.2307/2937231

Felicioli A, Sagona S, Galloni M, Bortolotti L, Bogo G, Guarnieri M, Nepi N (2018) Effects of non-protein amino acids on survival and locomotion of Osmia bicornis. Insect Mol Biol 27:556-563. https://doi.org/10.1111/imb.12496

Filella I, Bosch J, Llusià J, Peñuelas J (2011) Chemical cues involved in the attraction of the oligolectic bee Hoplitis adunca to its host plant Echium vulgare. Biochem Syst Ecol 39:498-508. https://doi.org/10.1016/j.bse.2011.07. 008

Fisogni A, Cristofolini G, Rossi M, Galloni M (2011) Pollinator directionality as a response to nectar gradient: promoting outcrossing while avoiding geitonogamy. Plant Biol 13:848-856. https://doi.org/10.1111/j.1438-8677.2011. 00453.x
Fisogni A, Rossi M, Sgolastra F, Bortolotti L, Gogo G, de Manincor N, Quaranta M, Galloni M (2016) Seasonal and annual variations in the pollination efficiency of a pollinator community of Dictamnus albus L. Plant Biol 18:445-454. https://doi.org/10.1111/plb.12417

Gade G, Auerswald L (2002) Beetles' choice proline for energy output: control by AKHs. Comp Biochem Phys B 132:117-129. https://doi.org/10.1016/S10964959(01)00541-3

Gardener MC, Gillman MP (2002) The taste of nectar-a neglected area of pollination ecology. Oikos 98:552-557. https://doi.org/10.1034/j.1600-0706.2002.980322.x

Hansen K, Wacht S, Seebauer H, Schnuch M (1998) New aspects of chemoreception in flies. Ann N Y Acad Sci 855:143-147. https://doi.org/10.1111/j.1749-6632.1998. tb10556.x

Harder L (1986) Effects of nectar concentration and flower depth on flower handling efficiency of bumble bees. Oecologia 69:309-315. https://doi.org/10.1007/ BF00377639

Harper DAT (1999) Numerical palaeobiology: computer-based modelling and analysis of fossils and their distributions. Wiley, New York

Hendriksma HP, Oxman KL, Shafir S (2014) Amino acids and carbohydrate tradeoffs by honeybee nectar foragers and their implications for plant-pollinator interactions. J Insect Physiol 69:56-64. https://doi.org/10.1016/j.jinsphys.2014. 05.025

Hubálek Z (2000) Measures of species diversity in ecology: an evaluation. Folia Zool 49:241-260

Inouye DW, Waller GD (1984) Responses of honeybees (Apis mellifera) to amino acid solutions mimicking floral nectars. Ecology 65:618-625. https://doi.org/10.2307/1941424

Irwin RE, Cook D, Richardson LL, Manson JS, Gardner DR (2014) Secondary compounds in floral rewards of toxic rangeland plants: impacts on pollinators. J Agric Food Chem 62:7335-7344. https://doi.org/10.1021/jf500521w

Iwasa Y, de Jong TJ, Klinkhamer PGL (1995) Why pollinators visit only a fraction of the open flowers on a plant-the plants point-of-view. J Evol Biol 8:439. https://doi.org/10.1046/j. 1420-9101.1995.8040439.x

Jacquemart AL, Buyens C, Hérent MF, Quetin-Leclercq J, Lognay G, Hance T, Quinet M (2019) Male flowers of Aconitum compensate for toxic pollen with increased floral signals and rewards for pollinators. Sci Rep 9:16498. https://doi.org/10.1038/s41598-019-53355-3

Josens R, Farina W (2001) Nectar feeding by the hovering hawk moth Macroglossum stellatarum: intake rate as a function of viscosity and concentration of sucrose solutions. J Comp Physiol 187:661-665. https://doi.org/10.1007/s00359-0010238-x

Kim W, Gilet T, Bush JW (2011) Optimal concentrations in nectar feeding. PNAS 108:16618-16621. https://doi.org/ 10.1073/pnas. 1108642108

Klinkhamer PGL, de Jong TJ (1990) Effects of plant size, plant density and sex differential nectar reward on pollinator visitation in the protandrous Echium vulgare. Oikos 57:399-405. https://doi.org/10.2307/3565970

Konarska A, Masierowska M (2020) Structure of floral nectaries and female-biased nectar production in protandrous species Geranium macrorrhisum and Geranium phaeum. 
Protoplasma 257:501-523. https://doi.org/10.1007/ s00709-019-01454-3

Langenberger MW, Davis AR (2002) Temporal changes in floral nectar production, reabsorption, and composition associated with dichogamy in annual caraway (Carum carvi; Apiaceae). Am J Bot 89:1588-1598. https://doi.org/ 10.3732/ajb.89.10.1588

Lázaro A, Nielsen A, Totland $\varnothing$ (2010) Factors related to the inter-annual variation in plants' pollination generalization levels within a community. Oikos 119:825834. https://doi. org/10.1111/j.1600-0706.2009.18017.x

Lucchetti MA (2017) Pyrrolizidine alkaloids: occurrance in bee products and impact on honeybees (Apis mellifera $\mathrm{L}$.). $\mathrm{PhD}$ Dissertation, Faculty of Science, Institute of Biology, University of Neuchâtel, Switzerland

Lucchetti MA, Glauser G, Kilchenmann V, Dübecke A, Beckh G, Praz C, Kast C (2016) Pyrrolizidine alkaloids from Echium vulgare in honey originate primarily from floral nectar. J Agric Food Chem 64:5267-5273. https://doi.org/ 10.1021/acs.jafc.6b02320

Magurran A (2004) Measuring biological diversity. Blackwell Science Ltd, Oxford

Melser C, Rademaker M, Klinkhamer PGL (1997) Selection on pollen donors by Echium vulgare (Boraginaceae). Sex Plant Reprod 10:305-312. https://doi.org/10.1007/ s004970050103

Melser C, Bijleveld A, Klinkhamer PGL (1999) Late-acting inbreeding depression in both male and female function of Echium vulgare (Boraginaceae). Heredity 83:162-170. https://doi.org/10.1046/j.1365-2540.1999.00568.x

Michener CD (2003) The social behaviour of the bees: a comparative study. Annu Rev Entomol 14:299-342. https://doi. org/10.1007/BF02223852

Micheu S, Crailsheim K, Leonhard B (2000) Importance of proline and other amino acids during honeybee flight (Apis mellifera carnica POLLMANN). Amino Acids 18:157-175. https://doi.org/10.1007/s007260050014

Mitchell BK, Harrison GD (1984) Characterization of galeal chemosensilla in the adult Colorado beetle, Leptinotarsa decemlineata. Physiol Entomol 9:49-56. https://doi.org/ 10.1111/j.1365-3032.1984.tb00680.x

Nepi M (2014) Beyond nectar sweetness: the hidden ecological role of non protein amino acids in nectar. J Ecol 102:108-115. https://doi.org/10.1111/1365-2745.12170

Nepi M, Stpiczyńska M (2006) Nectar resorption and trans location in Cucurbita pepo L. and Platanthera chlorantha Custer (Rchb.). Plant Biol 9:93-100. https://doi.org/10. 1055/s-2006-924287

Nepi M, Stpiczyńska M (2008) Do plants dynamically regulate nectar features through sugar sensing? Plant Signal Behav 3(10):874-876. https://doi.org/10.4161/psb.3.10.6228

Nepi M, Cresti L, Guarnieri M, Pacini E (2011) Dynamics of nectar production and nectar homeostasis in male flowers of Cucurbita pepo L. Int J Plant Sci 172:183-190. https:// doi.org/10.1086/657648

Nepi M, Soligo C, Nocentini D, Abate M, Guarnieri M, Cai G, Bini L, Puglia M, Bianchi L, Pacini E (2012) Amino acids and protein profile in floral nectar: much more than a simple reward. Flora 207:475-481. https://doi.org/10. 1016/j.flora.2012.06.002
Nicolson SW (2007) Nectar consumers. In: Nicolson SW, Nepi M, Pacini E (eds) Nectaries and nectar. Springer, Dordrecht, pp 289-342

Nicolson SW, Thornburg RW (2007) Nectar chemistry. In: Nicolson SW, Nepi M, Pacini E (eds) Nectaries and nectar. Springer, Dordrecht, pp 215-264

Nocentini D, Pacini E, Guarnieri M, Nepi M (2012) Flower morphology, nectar traits and pollinators of Cerinthe major (Boraginaceae- Lithospermeae). Flora 207:186-196. https://doi.org/10.1016/j.flora.2012.01.004

Nocentini D, Pacini E, Guarnieri M, Martelli D, Nepi M (2013) Intrapopulation heterogeneity in floral nectar attributes and foraging insects of an ecotonal Mediterranean species. Plant Ecol 214:799-809. https://doi.org/10.1007/s11258013-0204-z

Ohashi K, Yahara T (2001) Behavioral responses of pollinators to variation in floral display size and their influence on the evolution of floral traits. In: Chittka L, Thomson JD (eds) Cognitive ecology of pollination. Cambridge University Press, Cambridge, pp 274-296

Pacini E, Nepi M, Vesprini JL (2003) Nectar biodiversity: a short review. Plant Syst Evol 238:7-21. https://doi.org/10. 1007/s00606-002-0277-y

Pappers SM, de Jong TJ, Klinkhamer PGL, Meelis E (1999) Effects of nectar content on the number of bumblebee approaches and the length of visitation sequences in Echium vulgare (Boraginaceae). Oikos 87:580-586. https://doi.org/10.2307/3546822

Pérez-Barrales R, Arroyo J, Armbruster WS (2007) Differences in pollinator faunas may generate geographic differences in floral morphology and integration of Narcissus papyraceus (Amaryllidaceae). Oikos 116:1904-1918. https://doi.org/ 10.1111/j.0030-1299.2007.15994.x

Petanidou T (2007) Ecological and evolutionary aspects of floral nectars in Mediterranean habitats. In: Nicolson SW, Nepi M, Pacini E (eds) Nectaries and nectar. Springer, Dordrecht, pp 343-375

Petanidou T, Van Laere A, Ellis WN, Smets EF (2006) What shapes amino acid and sugar composition in Mediterranean floral nectars? Oikos 115:155-169. https://doi.org/10. 1111/j.2006.0030-1299.14487.x

Petanidou T, Kallimanis AS, Tzanopoulos J, Sgardelis SP, Pantis JD (2008) Long-term observation of a pollination network: fluctuation in species and interactions, relative invariance of network structure and implications for estimates of specialization. Ecol Lett 11:564-575. https://doi. org/10.1111/j.1461-0248.2008.01170.x

Proctor M, Yeo P, Lack A (1996) The natural history of pollination. Timber Press, Portland, OR

Pyke GH (1978) Optimal foraging in bumblebees and coevolution with their plants. Oecologia 36:281-293. https://doi. org/10.1007/BF00348054

Rademaker MCJ, de Jong TJ, Van der Meijden E (1999) Selfing rates in natural populations of Echium vulgare: a combined empirical and model approach. Funct Ecol 13:828-837. https://doi.org/10.1046/j.1365-2435.1999.00384.x

Ranjbar MH, Gherekhloo J, Soltani A (2017) Diversity and evenness of weeds in forage corn field under different tillage systems. J Plant Prot 31:213-222. https://doi.org/10. 22067/jpp.v0i0.45478 
Rathcke BJ (1992) Nectar distributions, pollinator behaviour and plant reproductive success. In: Hunter MD, Ohgushi T, Price PW (eds) Effects of resource distribution on animalplant interactions. Academic Press, Cambridge, pp 113-138

Romeis J, Wackers FL (2000) Feeding responses by female Pieris brassicae butterflies to carbohydrates and amino acids. Physiol Entomol 25:247-253. https://doi.org/10. 1046/j.1365-3032.2000.00188.x

Schoonhoven LM, van Loon JJA, Dicke M (2005) Insect-plant biology, 2nd edn. Oxford University Press, Oxford

Seo HJ, Song J, Yoon HJ, Lee KY (2019) Effects of nectar contents on the foraging activity of honeybee (Apis mellifera) on Asian pear (Pyrus pyrifolia Nakai). Sci Hortic 245:185-192. https://doi.org/10.1016/j.scienta.2018.10. 009

Shelp BJ, Bown AW, Zarei A (2017) 4-aminobutyrate (GABA): a metabolite and signal with practical significance. Botany 95:1015-1032. https://doi.org/10.1139/cjb-2017-0135

Stevenson PC, Nicolson SW, Wright GA (2017) Plant secondary metabolites in nectar: impacts on pollinators and ecological functions. Funct Ecol 31:65-75. https://doi.org/ $10.1111 / 1365-2435.12761$

Stöckl AL, Kelber A (2019) Fuelling on the wing: sensory ecology of hawkmoth foraging. J Comp Physiol 205:399-413. https://doi.org/10.1007/s00359-019-013282

Stpiczyńska M, Nepi M, Zych M (2015) Nectaries and malebiased nectar production in protandrous flowers of Angelica sylvestris L. (Apiaceae). Plant Syst Evol 301:1099-1113. https://doi.org/10.1007/s00606-0141152-3
Teulier L, Weber JM, Crevier J, Darveau CA (2016) Proline as a fuel for insect flight: enhancing carbohydrate oxidation in hymenopterans. Proc R Soc B 283:20160333. https://doi. org/10.1098/rspb.2016.0333

Thompson JN (2006) The geographic mosaic of coevolution, 2nd edn. University of Chicago Press, Chicago

Tiedge K, Lohaus G (2017) Nectar sugars and amino acids in day- and night-flowering Nicotiana species are strongly shaped by pollinators' preferences than organic acids and inorganic ions. PLoS ONE 12:1-25. https://doi.org/10. 1371/journal.pone. 0176865

Verhoeven KJF, Simonsen KL, McIntyre LM (2005) Implementing false discovery rate control: increasing your power. Oikos 108:643-647. https://doi.org/10.1111/j. 0030-1299.2005.13727.x

Wacht S, Lunau K, Hansen K (2000) Chemosensory control of pollen ingestion in the hoverfly Eristalis tenax by labellar taste hairs. J Comp Physiol A 186:193-203. https://doi.org/ $10.1007 / \mathrm{s} 003590050019$

Willmer P, Finlayson K (2014) Big bees do a better job: intraspecific size variation influences pollination effectiveness. J Pollinat Ecol 14:244-254. https://doi.org/10. 26786/7603(2014)22

Wright GA, Baker DD, Palmer MJ, Stabler D, Mustard A, Power EF, Borland AM, Stevenson PC (2013) Caffeine in floral nectar enhances a pollinator's memory of reward. Science 339:1202-1204. https://doi.org/10.1126/science. 1228806

Publisher's Note Springer Nature remains neutral with regard to jurisdictional claims in published maps and institutional affiliations. 